\title{
The Impact of a Coronavirus Epidemic on China's Public Debt Ratio Growth
}

\section{TÖRÖK}

PhD, University instructor, University of Debrecen, Faculty of Engineering, Department of Engineering Management and Enterprise, Qualified Lecturer, Chamber of Hungarian Auditors, Hungary, dr.torok.laszlo@eng.unideb.hu

\begin{abstract}
Public opinion in the economic profession is strongly preoccupied with the expected negative economic effects of the coronavirus epidemic. Among the consequences, special attention is paid to the increase in the gross debt of the states. Indeed, based on conventional economic knowledge, it is clear to everyone that the economic downturn and the increase in government sector expenditure will directly lead to a sharp rise in government debt. The study aims to predict an increase in China's government debt ratio using a macroeconomic model. The study will quantify the rate of increase in China's public debt based on four theoretically possible scenarios for the course of the coronavirus epidemic. I am aware that it is difficult to apply conventional economic knowledge to China's statecapitalist system. This is explained by the fact that the theories of the socialist economic model do not apply to China either. At the same time, the functioning of China's economy is closer to that of market-based economies, but the country's structure as a whole cannot be integrated into this framework either. But models describing the economic development of developing national economies cannot be applied to the country either. Nonetheless, I attempt to use conventional economic economics to attempt to quantify the impact of the coronavirus epidemic on China's sovereign debt ratio. China's public debt growth rates calculated under different outbreak scenarios are different, but none show an increase that would call into question the financing of China's public debt.
\end{abstract}

Keywords: coronavirus epidemic, public debt, China

\section{Introduction}

The study of government indebtedness has been a central theme of macroeconomic research since the inception of modern economies. Gross consolidated government debt is equal to the cumulative amount of the consolidated general government deficit. In parallel, there have been and will be items in the past that have not appeared or will not appear in short supply. If the expenditures of the entire general government sector exceed its revenues in a given year, the government can issue debt securities (typically treasury bills and government bonds) or take out loans to finance the resulting deficit. The stock of debt items issued to finance the deficit accumulated over the years is the sovereign debt of a state [1]. The state should pay interest on its existing debt to the holders of debt securities. In an indebted country, the so-called primary balance of the state, calculated without interest payments, is in balance, even if interest payments alone lead to a deficit.

In addition to the lack of the entire government sector, the development of the public debt of a national economy is mainly influenced by economic growth and the real interest rate over the country's inflation. 
In addition to these factors, the ratio of debt in national currency and foreign currency within public debt can also be an influencing factor. The study will show the determining role of these factors in China's expected government debt in the future.

\section{Literature Review and Presentation of Background}

\subsection{Theoretical Values of Sovereign Public Debt}

The view that the indebtedness of the state has only negative consequences is fundamentally wrong. In some cases, the development of a given national economy can be well served if the state has sovereign debt. However, it can have a positive effect if this debt remains relatively stable to the GDP of the given national economy. The debt stock is useful to some extent, so it is not optimal to reduce a country's debt level to zero. The positive economic effects of public debt can be illustrated by the optimizing consequences of borrowing. Like all borrowing, you can help create investments that would not otherwise be possible without a lack of resources. Advantageously, the positive effects and returns of these investments effectively help to repay the debt incurred and, besides, can exert other optimal effects.

There is no exact rule in economics as to what is the optimal rate of debt for a given national economy. Several studies have examined the extent to which public debt is already harming the economic growth of a given national economy. The only requirement for this level of government debt is that it is good to approach the level as a share of GDP at a "satisfactory pace " [2]. Examining this [3], it was concluded that public debt above 90 percent of GDP reduces the growth of a given national economy. In contrast [4], it has been found that there is no large difference in the average and median GDP growth of countries with debt levels below or above the $90 \%$ threshold. They conclude that government debt and GDP growth varied significantly across countries and periods. The 60 percent government debt-to-GDP ratio is often referred to as a prudential constraint for developed countries. This suggests that exceeding this limit would jeopardize fiscal sustainability. For developing and emerging economies, the proposed government debt-to-GDP ratio is 40 percent, which should not be exceeded permanently in the long run. These benchmarks are recommended by the [5]. Other authors have found that there is no evidence for the existence of a specific threshold for the optimal rate of government debt [6]. Until now, economics has not been able to determine the optimal ratio of public debt. In the global economy, some countries can sustain their economies even with very high levels of public debt [7]

\subsection{Presentation of China's Pre-Epidemic Coronavirus Economy}

China became the world's second-largest economy at the end of 2010 after Japan's third-place economy remained sustained slow. In terms of purchasing power parity, 2014 became the largest in the Chinese economy. China's GDP has nearly tripled in the last ten years: it is expected to grow from \$ 5.1 trillion in 2009 to $\$ 14,420$ billion by 2019. Over the past ten years, China's GDP growth rate has slowed, quite accurately halved, mainly due to its growing base. Even so, the G20 can show the fastest growth with average annual GDP growth of six percent. The country has the world's largest foreign exchange reserves worth $\$ 3.2$ trillion, in addition to holding most of its minerals, most of which are coal and rare 
metals. Of the world's 500 largest companies, 110 are Chinese, with 80 percent of their revenue coming domestically.

In 2013, China gained the position of the world's largest exporter and also the country with the largest trade, ranking second in terms of imports after the US. The country's consumer market has expanded the fastest in the past decade, by eight percent a year last year, and already accounts for more than 40 percent of GDP. The basis for the expansion of the market is the growing income of the people, as well as the strengthening of the Chinese middle class and, at the same time, the rising demand for consumption. The structure of the Chinese economy has changed in recent decades. Exposure to exports decreased significantly, which was offset by a significant strengthening of the internal market. In most technologies, China is already following global standards, Chinese technology companies have grown significantly, but are still vulnerable to imports in several areas. The most important economic policy step of the last decade has been the acceleration of foreign infrastructure developments [8].

\subsection{Development of China's Sovereign Gross Government Debt}

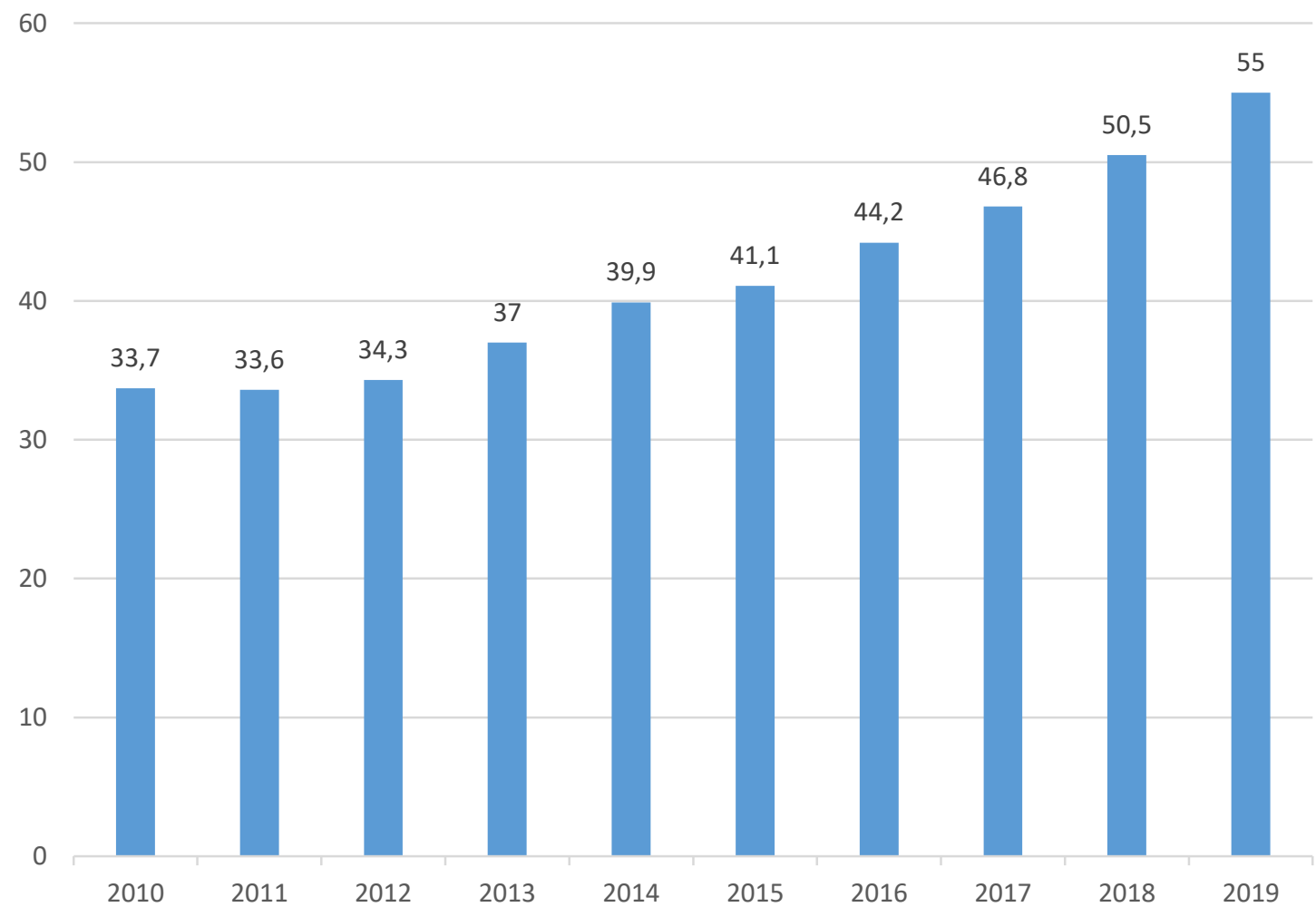

Figure 1. Development of China's gross government debt as a percentage of GDP (2010-2019), [9], own compilation

The chart clearly shows that China's sovereign domestic debt ratio has risen 2.37 percent on an annual average. This is significantly less than the dynamics of economic growth. This also means that the growing base of the Chinese economy was fundamentally based on the expansion of the company's internal resources and not just on state-provided development aid. In terms of government debt as a share of GDP, China remains only in the middle of the global rankings. It should be noted here that the officially reported figures for China's total government debt do not include the so-called contingent liabilities of the government. The debt ratio would be several percent higher. China's weight in the global 
economy is also shown by the fact that the total public debt of emerging countries reached 170 percent of GDP in 2018. In 2010, the government debt ratio was still only 114 percent in emerging countries, while without China, this figure would be only 107 percent [10].

\subsection{Impact of Coronavirus Epidemic on China's Economy}

It is not the purpose of this study to analyze in detail the effects of the coronavirus epidemic on the Chinese economy as a whole. However, the most relevant implications need to be briefly presented before analyzing the effects on public debt. The Chinese economy may slow faster than expected this year and the Communist Party of China's (CPC) growth target of 5.6 percent will not be met.

In recent months, the Chinese economy has faced many factors that hinder growth. Such factors include the consequences of a trade war with the United States or the demographic situation of the country. This is reflected in the fact that 15 percent of the population is over 65 years of age. In this context, the COVID19 epidemic represents a further shock, significantly exacerbating the existing economic difficulties. The country is in a particularly difficult position in key markets for China, such as Europe and North America, which buy up 30 percent of exports. It is trivial that these factors will dampen the performance of the Chinese economy this year. The Chinese authorities have taken steps to offset the impact of the epidemic on the economy. For example, the People's Bank of China (PBOC) has so far focused on targeted measures such as interest rate cuts. Although the decisions will allow more flexibility for the economy, China needs to implement aggressive monetary and fiscal easing if it wants to stabilize its economy. On the fiscal front, additional infrastructure investments are being sought to offset the shock caused by the coronavirus. This will increase indebtedness at the local level and put further pressure on already distressed banks, highly indebted companies, and the moderately indebted state [11].

According to conventional economic theory, China's economy is also burdened by three factors that will cause an increase in public debt. The first of these is the decline in economic output. This will be reflected in the decline in GDP. The extent of this cannot be determined precisely, according to benchmark estimates, GDP decline is expected to be around 3 percent. Due to several months of economic stagnation, the output from the manufacturing and service sectors will decline significantly. The second factor is the expected deficit of the Chinese budget. This is projected to be around 3.1 percent. The Chinese state will give a lot of support to the economy to make it work. Households also need support, for example, due to rising unemployment. Support will be needed to prevent mass impoverishment. / It should be noted here that the unemployment benefit system in China differs from the structure of developed economies. In China, the state unemployment benefit system is not developed, it is only possible to register and claim benefits in large cities. The Chinese state claims that at the peak of the epidemic, even after the complete shutdown of several provinces, unemployment was only 6.2 percent, which would officially mean a mass of 26 million. However, according to surveys by independent economists, the real number is much higher: almost 80 million people may have lost their jobs [12]/. Due to the decline in GDP, the economy and households will pay much fewer taxes and social security contributions to the state, resulting in a decrease in general government revenue.

Finally, the third factor that will affect China's government debt is the future rate of real interest rates on government bonds. The real interest is the excess of interest that is paid to the government in favor 
of creditors over inflation on government bonds that finance government debt. Real interest rates are not expected to rise because a huge amount will not be needed to finance China's public debt. Investors will not become riskier with Chinese government debt financing, so real interest rate growth is not expected.

\section{Data and Methodology}

\subsection{Government Debt Forecast Data}

The expected government debt ratio of a national economy depends fundamentally on the ratio of economic growth to real interest rates and the primary balance of the general government sector as a whole. Determining the value of the economic downturn at the time of the study is one of the relevant factors. To define this, I will use reliable data following the emergence of the coronavirus epidemic in China. I will use an estimate of baseline data for 2020 [13], where GDP is expected to decline by 3 percent. To estimate the primary balance of the budget [14], I will start from its forecast of 3.1 percent. It should be noted here that China's budget deficit is officially smaller than the deficit according to the IMF methodology.

The real interest rate forecast also contains many uncertainties. Despite the uncertainty, both fiscal and monetary stimulus began in emerging economies, including China, in the fight against the coronavirus epidemic. This theoretically predicts a minimal change in current interest rates and inflation. There is no reliable source of data to forecast the real interest rate, so I calculate it myself with the difference between the interest rate on Chinese long-term government bonds and inflation. The forecast for Chinese inflation [15] and government bond interest rates [16], so I was able to make a forecast for the real interest rate, which is 0.3 percent by 2020 .

\subsection{Methodology for Forecasting Public Debt}

The following macroeconomic model is suitable for forecasting the expected public debt of a national economy:

$$
b_{t}=\left[\left(1+r_{t-1}\right) /\left(1+g_{t^{-} 1}\right)\right] b_{t-1}-p b_{t}
$$

In this model, $\mathrm{b}$ and $\mathrm{pb}$ denote government debt as a share of GDP and the primary balance of the budget, $r$ the real interest rate, and $g$ the economic growth. The subscript $t$ denotes the current year and the index $\mathrm{t}-1$ denotes the year preceding the current year.

The methodology used bears a resemblance to the procedure described in a study by [17]. In these the input variables are the same, the difference is in the difference operator. Its applicability is somewhat limited by the fact that the real interest rate shows a positive value. In his study [18], he further developed Domar's formula by making the magnitude of expected inflation dependent on the debt-toGDP ratio. The expected future government debt ratio of a national economy can also be calculated using the VAR model. The use of the VAR model is widespread, see for example [19]. I did not use this model because the data needed to calculate VAR for China was missing. Unfortunately, international databases 
contain only incomplete data on the Chinese economy, in many cases unreliable. Therefore, I chose the method used, as relatively reliable data could be found in databases.

As a result of the coronavirus epidemic, China's expected gross government debt will increase. However, the development of the level of public debt does not matter what scenario the epidemic will take place. In a total of four different versions, I examine how much Chinese government debt will be by the end of the epidemic. The four possible scenarios of the epidemic can describe the following shapes: shapes $\mathrm{V}$, W, U1, and U2 / for more details on these possible scenarios [20] /. I set up a total of five different scenarios, depending on the expected course of the coronavirus epidemic over time. These are as follows: In the case of a 1 / V-shaped track, it is likely that the initial major economic downturn will be followed by a rebound of similar dynamics and that the recession will end by the end of this year at the latest. Suffering a one-off shock, China will return to its pre-crisis economic operation from 2021 onwards. In the case of a 2 / W-shaped track, the one-time large-scale economic downturn is followed by a sudden bounce, and then all this is repeated once a year. The impact of this may be more drastic overall compared to the first scenario. In summary, the $\mathrm{V}$ - and $\mathrm{W}$-shaped trajectories predict stronger transient global economic effects of the global coronavirus epidemic in China. 3 / In the case of the U / 1 trajectory, the one-off shock-like economic downturn of 2020 will remain at a low point throughout 2020. 4 / In the case of the $\mathrm{U} / 2$-shaped run, the decline of the previous year will drag on and remain at a low point throughout 2021. Scenarios U / 1 and U / 2 will show the effects of the global coronavirus epidemic on China's rising government debt ratio. China's economic forecasts for 2022 suggest that the coronavirus epidemic will end by that year. This year, the country's economy will return to the 5.6 percent economic growth forecast in the year before the epidemic, real interest rates are expected at 0.3 percent, and the general government deficit will fall to 2 percent.

\begin{tabular}{|c|c|c|c|c|c|c|c|c|c|c|c|c|c|c|c|}
\hline \multirow[t]{3}{*}{ Country } & \multicolumn{5}{|c|}{ GDP change (g) } & \multicolumn{5}{|c|}{ Real interest rate (r) } & \multicolumn{5}{|c|}{ The budget deficit (pb) } \\
\hline & \multicolumn{3}{|c|}{2020} & \multirow{2}{*}{\begin{tabular}{|c|}
2021 \\
U/2 shap. \\
\end{tabular}} & \multirow{2}{*}{\begin{tabular}{|c|}
2022 \\
$\begin{array}{c}\text { After } \\
\text { the } \\
\text { crisis }\end{array}$ \\
\end{tabular}} & \multicolumn{3}{|c|}{2020} & \multirow{2}{*}{\begin{tabular}{|c|}
2021 \\
$\begin{array}{c}\mathrm{U} / 2 \\
\text { shap. }\end{array}$
\end{tabular}} & \multirow{2}{*}{$\begin{array}{c}2022 \\
\begin{array}{c}\text { After } \\
\text { the } \\
\text { crisis }\end{array} \\
\end{array}$} & \multicolumn{3}{|c|}{2020} & \multirow{2}{*}{\begin{tabular}{|c|}
2021 \\
$\begin{array}{c}\text { U/2 } \\
\text { shap. }\end{array}$
\end{tabular}} & \multirow{2}{*}{$\begin{array}{c}2022 \\
\text { After } \\
\text { the } \\
\text { crisis }\end{array}$} \\
\hline & V-shap. & W-shap. & $\begin{array}{c}\mathrm{U} / 1 \\
\text { shap. }\end{array}$ & & & V. shap. & W. shap. & $\begin{array}{c}\mathrm{U} / 1 \\
\text { shap. }\end{array}$ & & & $\begin{array}{c}\text { V. } \\
\text { shap. }\end{array}$ & $\begin{array}{c}\text { W. } \\
\text { shap. }\end{array}$ & $\begin{array}{c}\mathrm{U} / 1 \\
\text { shap. }\end{array}$ & & \\
\hline China & $-3,0$ & $-4,5$ & $-4,0$ & $-3,9$ & 5,6 & 0,3 & 0,3 & 0,3 & 0,8 & 0,3 & $-3,1$ & $-4,5$ & $-4,0$ & $-3,9$ & $-2,0$ \\
\hline
\end{tabular}

Table 1. Input values of the macroeconomic model as a percentage of Chinese GDP (2020-2022),[13],[14],[15]

(Base year used for calculations 2019, data: government debt 55, economic growth 6.1 and real interest rate 0.35 percent)

\section{Results}

Using the input data, the table below shows the ratio of China's expected government debt to GDP ratio soon. Data were calculated depending on different coronavirus epidemic trajectories.

\begin{tabular}{|c|c|c|c|c|c|c|c|}
\hline Country & 2019 & \multicolumn{3}{|c|}{2020} & 2021 & 2022 & $\begin{array}{c}\text { Change by } \\
\text { the end of } \\
\text { the crisis }\end{array}$ \\
\cline { 2 - 8 } & $\begin{array}{c}\text { Base } \\
\text { year }\end{array}$ & $\begin{array}{c}\text { V- } \\
\text { shaped }\end{array}$ & $\begin{array}{c}\text { W- } \\
\text { shaped }\end{array}$ & $\begin{array}{c}\text { U/1 } \\
\text { shaped }\end{array}$ & $\begin{array}{c}\text { U/2 } \\
\text { shaped }\end{array}$ & $\begin{array}{c}\text { After the } \\
\text { crisis }\end{array}$ & $\begin{array}{c}(2021- \\
2019)\end{array}$ \\
\hline China & 55,0 & 55,0 & 60,9 & 61,6 & 61,8 & 60,9 & 6,8 \\
\hline
\end{tabular}

Table 2. Expected government debt ratio increases in China for different epidemic scenarios, as a percentage of GDP (2019-2022), own calculation 
The data in the previous table is illustrated in the figure below:

8

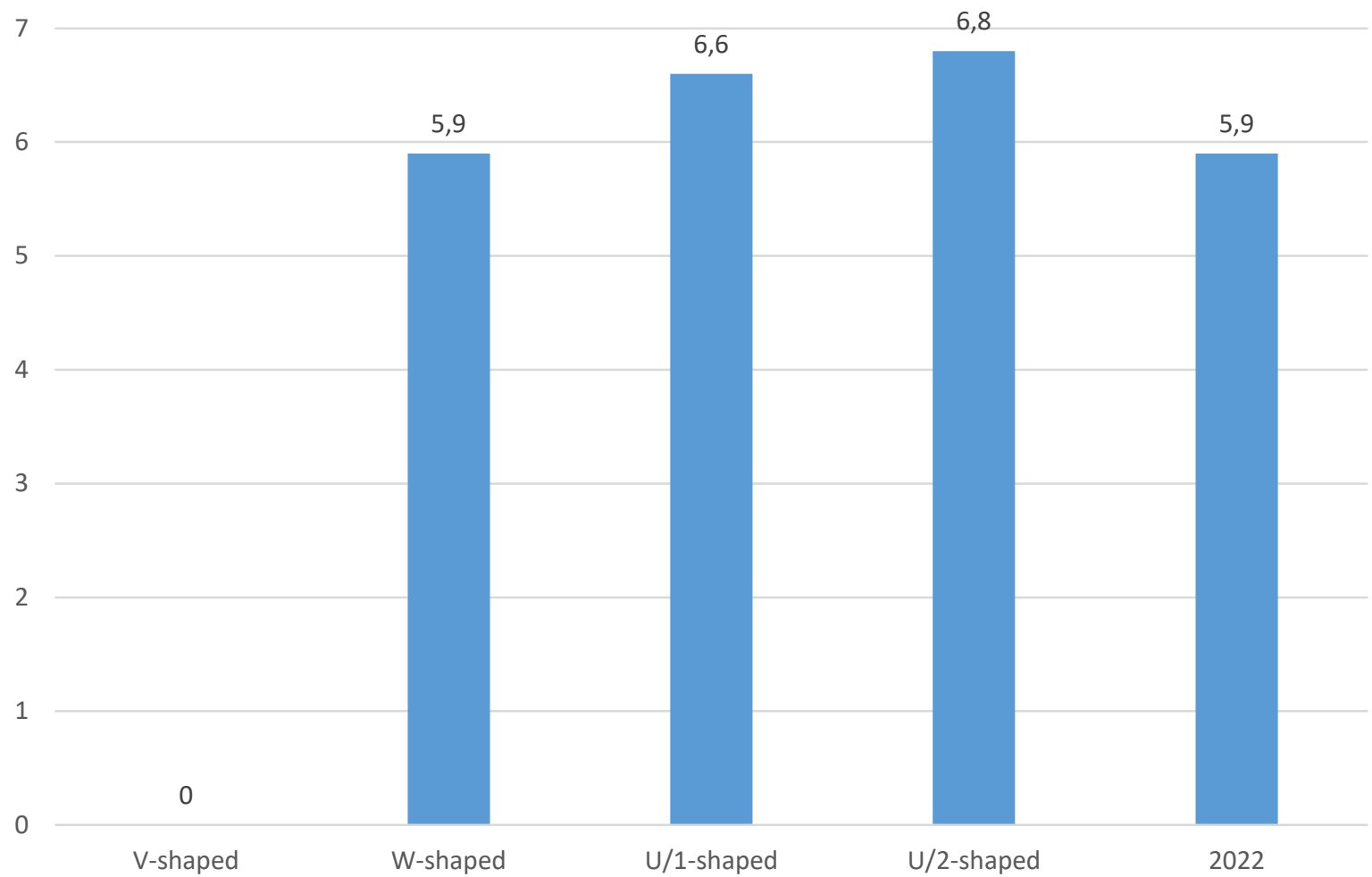

Figure 2. Increase in China's public debt ratio as a function of different epidemic trajectories as a percentage of GDP (2019-2022) own compilation

Only in the event of a V-shaped epidemic will China's public debt not rise. This is explained by the spillover effect of the strong economic growth in 2019. The rates of change in the government debt ratio show a varied picture depending on each coronavirus epidemic scenario. It can be seen that the value of the government debt ratio does not change in the case of the V-path, despite the projected 3\% decline in GDP. One explanation for this is that the positive impact of the 6.1 percent dynamic economic growth in 2019 will be carried over to the crisis-stricken 2020. The 0.3 percent value of the real interest rate also plays a role in ensuring that the rate does not change significantly. The just-positive 0.3 percent shows that the Chinese budget can finance its public debt with a low-yield premium. This means that there are no high costs of financing China's public debt. The combination of these two effects is sufficient to ensure that the total government deficit expected to be around 3.1 percent does not raise China's public debt ratio.

\section{Conclusions}

There would be a drastic increase in the rate of increase if the coronavirus epidemic were to return in the second half of this year and therefore the economy would have to be shut down completely or largely again. This position is indicated by the $\mathrm{W}$-shaped trajectory. In this case, the government debt ratio would increase by 5.9 percent, slightly more than the percentage increase between 2018 and 2019 . 
China's gross government debt ratio would increase the most if the coronavirus were present even in 2021 and because of this, the Chinese economy would perform well below its potential output. Theoretically, this case cannot be ruled out either, for example, because the antidote to the virus would not be available even next year. This theoretical scenario is represented by the $U$ / 1 and $U$ / 2 epidemic trajectories. Finally, the data suggest that if the coronavirus epidemic were to be eradicated by 2022, its antidote would be available, and therefore dynamic economic growth would return. With the projected 5.6 percent GDP growth, a moderate decline in government debt would begin and materialize in just over 60 percent in 2022 .

An increase in China's public debt will be inevitable as a result of Covid-19. However, despite the rise in government debt, money market financing will not pose a significant difficulty to Chinese public finances.

The factors influencing the development of public debt are unpredictable for everyone. Several international organizations and think tanks have also made forecasts of the size of China's public debt due to the Covid-19 epidemic. I highlight one of the predictions here [21]. This shows that the IMF predicts more pessimistic values than the values calculated in my study. The organization forecasts a government debt ratio of 61.7 percent by 2020, 66.5 percent by 2021, and 71.2 percent by 2022 for China.

\section{References:}

[1] Arena, M. (2010) The Corporate Choice between Public Debt, Bank Loans, Traditional Private Debt Placements, and 144A Debt Issues, Review of Quantitative Finance and Accounting 36 (3), DOI: $10.1007 / \mathrm{s} 11156-010-0182-3$

[2] Teica, R. A. (2012) Analysis of the Public Debt Sustainability in the Economic and Monetary Union, Emerging Markets Queries in Finance and Business, Procedia Economics and Finance 3 (2012) pp. 1081 - 1087., DOI: 10.1016/S2212-5671(12)00277-8,

[3] Reinhart, C. M. Rogoff, K. S. (2010) Growth in a time of debt. American Economic Review: Papers \& Proceedings, 100., pp. 573-578., https://doi.org/10.1257/aer.100.2.573

[4] Herndon, T. Ash, M. Pollin, R. (2014) Does high public debt consistently stifle economic growth? A critique of Reinhart and Rogoff. Cambridge Journal of Economics, Vol. 38, 2, pp. 257-279., doi:10.1093/cje/bet075

[5] IMF (2010) From Stimulus to Consolidation: Revenue and Expenditure Policies in Advanced and Emerging Economies, Prepared by Fiscal Affairs Department, https://www.imf.org/external/np/pp/eng/2010/043010a.pdf, Download time: 06-07-2020.

[6] Pescatori, A. Sandri, D. Simon, J. (2014) Debt and Growth: Is There a Magic Threshold?, IMF Working Paper, 2014. Feb., https://doi.org/10.5089/9781484306444.001

[7] Takeo, H. Takatoshi, I. (2012): Defying Gravity: How Long Will Japanese Government Bond Prices Remain High? Working Paper 18287, https://doi.org/10.3386/w18287 
[8] McKinsey Global Institute (2019) China and the world: Inside the dynamics of a changing relationship, Full report June 2019, pp. 1-168.

[9]Tradingeconomics (2020b) China Government Debt to GDP, https://tradingeconomics.com/china/government-debt-to-gdp, Download time: 06-07-2020.

[10] World Bank (2020) The fourth wave, Rapid Debt Buildup, Global Economic Prospects, Chapter 4, 1-253., http://pubdocs.worldbank.org/en/662091574888364763/Global-Economic-ProspectsJanuary-2020-Topical-Issue-2.pdf, Download time: 01-08-2020.

[11] Coface Economic Publications (2020) Can China shield its economy from the impact of COVID-19? 1-4., https://www.coface.com/News-Publications/News/Can-China-shield-its-economy-fromthe-impact-of-COVID-19, Download time: 30-05-2020.

[12] CTV News (2020) 80 million Chinese may already be out of work. 9 million more will soon be competing for jobs, too, https://www.ctvnews.ca/health/coronavirus/80-million-chinese-mayalready-be-out-of-work-9-million-more-will-soon-be-competing-for-jobs-too-1.4933970, Download time: 3-07-2020.

[13] Euler Hermes (2020) Quarantined Trade losses: Covid-19 to cost USD 320 BN of trade everyquarter,https://www.eulerhermes.com/content/dam/onemarketing/ehndbx/eulerherme s_com/en_gl/erd/publications/the-watch/NW-2020_03_05_QuarantinedTrade.pdf, Download time: 01-08-2020.

[14] Global Times (2020) China's 2020 fiscal deficit target to exceed 3\%: economists, https://www.globaltimes.cn/content/1188403.shtml, Download time: 06-06-2020.

[15] Tradingeconomics (2020a) China inflation rate, https://tradingeconomics.com/china/inflationcpi, Download time: 06-07-2020.

[16] CEIC (2020) China Long Term Interest Rate, https://www.ceicdata.com/en/indicator/china/longterm-interest-rate, Download time: 02-06-2020.

[17] Domar, E. (1944). The "Burden of the Debt" and the National Income. The American Economic Review, 34(4), 798-827. Retrieved November 4, 2020, from http://www.jstor.org/stable/1807397

[18] Missale, A. Blanchard, O. J. (1994) The Debt Burden and Debt Maturity. American Economic Review, Vol. 84, 1. pp. 309-319.,

[19] King, R. G. Watson, M. W. (1997) Testing Long-Run Neutrality. Federal Reserve Bank of Richmond Economic Quarterly, Vol. 83. No. 3. pp. 69-101.

[20] FC (2020) U-shaped or V-shaped recovery? Here's your guide to the geometry of recessions. from https://www.fastcompany.com/90494041/u-shaped-or-v-shaped-recovery-heres-your-guideto-the-geometry-of-recessions, Download time: 07-07-2020.

[21] International Monetary Fund (2020) October 2020, Fiscal Policies to Address the Covid-19 Pandemic,https://www.imf.org/ /media/Files/Publications/fiscalmonitor/2020/October/Eng lish/ch1.ashx?la=en, Download time: 04-11-2020 